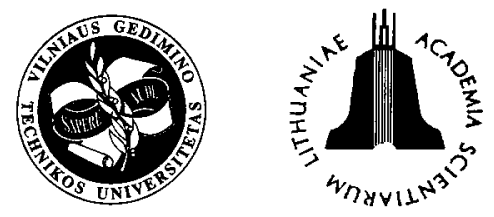

JOURNAL OF CIVIL ENGINEERING AND MANAGEMENT

http:/www.vtu.lt/english/editions

2003, Vol IX, No 4, 292-296

\title{
NUMERICAL TESTS OF STEEL BEAM-TO-COLUMN SEMI-RIGID CONNECTIONS
}

\author{
Kęstutis Urbonas ${ }^{1}$, Alfonsas Daniūnas ${ }^{2}$ \\ Dept of Steel and Timber Structures, Vilnius Gediminas Technical University, \\ Sauletekio al. 11, LT-2040 Vilnius, Lithuania \\ ${ }^{1}$ E-mail: kestutisur@centras.lt 2E-mail: alfonsas.daniunas@adm.vtu.lt
}

Received 20 Aug 2003; accepted 15 Nov 2003

\begin{abstract}
This paper presents an analysis of semi-rigid beam-to-column connections in which the beam is connected to column not at 90 degrees angle. Beam-to-column bolted end-plate connections that are subjected to pure bending were modelled by three-dimensional finite elements. Numerical modelling of connection covers the geometrical and material non-linearities as well as contact and separation between various components of connection. Moment-rotation M- $\Phi$ curves for modelled connections using numerical results are made and stress distribution in connection components is presented. The study shows a significant influence of inclination of beam and quantity and location of bolts on the joint rigidity.
\end{abstract}

Keywords: steel structures, semi-rigid joints, beam-to-column connections, moment-rotation curve, finite element method, numerical tests.

\section{Introduction}

Beam-to-column connections are usually divided into rigid or hinged connections. In the last decade the concept and practical application of semi-rigid joints has been increasingly used [1-5]. Depending on rigidity, the codes on design of steel structures EC $3[6,7]$ classify the connections into rigid, semi-rigid and hinged. The origination of such type of joints was stipulated by a need to specify the real behaviour of structures as accurately as possible. The more accurate knowledge of the behaviour of a structure allows the higher possibilities to reach the economical effect [8]. It is easier to install semi-rigid connections than the rigid ones, because the former need fewer stiffeners and bolts. The elements joined by semi-rigid connections may be of smaller crosssection than the hinged ones, because semi-rigid connections decrease the displacement of element if compared to hinged connection [9].

The variety of beam-to-column connections is very wide. Up till now all studies were carried out for beamto-column connections when the beam and the column make right angle. There are many connections where the beam is connected to the column not at right angle. Such type of connections has not been widely analysed and their rigidity characteristics not studied. It is not clear how the angle of beam inclination influences the rigidity of connection. No methodology has been developed for establishing the rigidity of such connections.
The behaviour of a semi-rigid connection is described by moment-rotation $M-\Phi$ curve of the joint $[2-7,10]$. Other forces acting in the joint do not have such significant effect on the joint rigidity and usually are not evaluated in calculations. Various methods may be used for establishment of M- $\Phi$ curves of semi-rigid joints: empirical, analytical, mechanical, numerical and experimental tests [11].

Numerical approach is generally based on using the finite element method. This method is applied for studying the behaviour of various types of connections [1216]. It can be used for evaluation of real behaviour of joint, such as interaction phenomena between different components of joint, the physical non-linearity of the material and the geometric non-linearity of the joint.

This paper presents the investigation results of analysis of semi-rigid not right angle beam-to-column bolted connections. The main focus is made on estimation of beam inclination, quantity and location of bolts on the rigidity and strength of the analysed type of connections. The analysis of connections is performed by finite element method.

\section{Description of the objects}

Beam-to-column connections shown in Fig 1 were analysed. Nine semi-rigid connections made of a beam bolted to a column were modelled. The beam and the 
a)

c)

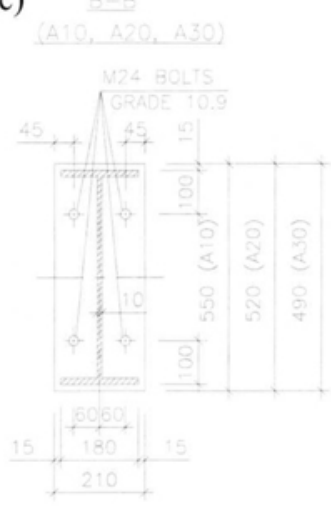

d)

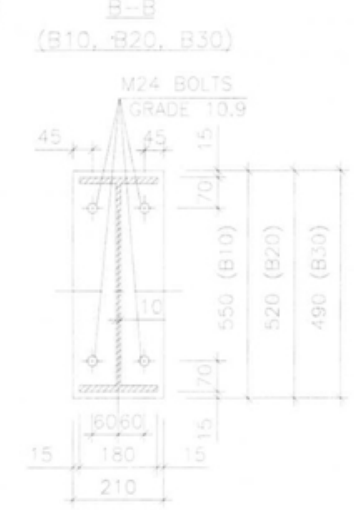

b)

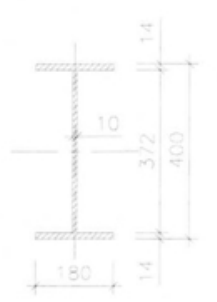

e)

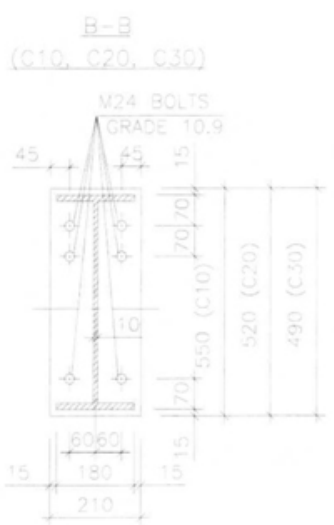

Fig 1. Beam-to-column connections details (mm): a) general view; b) section A-A; c) section B-B of connections A10, A20, $\mathrm{A} 30$; d) section $\mathrm{B}-\mathrm{B}$ of connections $\mathrm{B} 10, \mathrm{~B} 20, \mathrm{~B} 30$; e) section $\mathrm{B}-\mathrm{B}$ of connections $\mathrm{C} 10, \mathrm{C} 20, \mathrm{C} 30$

level contour make a $10^{\circ}$ angle (connections A10, B10, $\mathrm{C} 10$ ), $20^{\circ}$ angle (connections $\mathrm{A} 20, \mathrm{~B} 20, \mathrm{C} 20$ ) or $30^{\circ}$ angle (connections A30, B30, C30). Six connections (A10, A20, A30, B10, B20, B30) were with four bolts and three ones $(\mathrm{C} 10, \mathrm{C} 20, \mathrm{C} 30)$ with six bolts. Difference between connections A10, A20, A30 and B10, B20, $\mathrm{B} 30$ is in position of bolts.

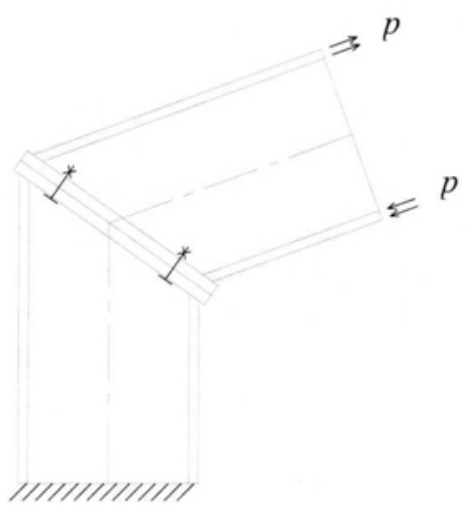

Fig 2. Loading and supporting scheme for all tested connections
The bending moment added at outside cross-section of the beam in clockwise direction, which is replaced by uniformly distributed load $p$ (Fig 2) and varies from zero to ultimate value. The ultimate value of bending moment, which can be added to connection, means the strength limit of semi-rigid joint.

Steel of the column, beam and end plates for all connections is $\mathrm{S} 275$ with yield limit $275 \mathrm{MPa}$. Bolt class is 10.9 with yield limit of bolt material $900 \mathrm{MPa}$. Modulus of elasticity for all elements is $2,10 \times 10^{11} \mathrm{~Pa}$.

\section{Modelling technique of connections by finite ele- ment method}

Modelling of beam-to-column bolted connection is deeply complex problem because it involves geometrical and material non-linearities, contact problem between components of connection as well as selection of suitable finite elements type for discretisation connection components.

The numerical tests were carried out by using the finite element code „Cosmos/M“" [17]. A three-dimen- 
sional finite element model was generated to represent the joint behaviour.

End plates of connections were modelled by TETRA4 4-node three-dimensional tetrahedral solid elements. These elements together with node-to-surface GAP elements can be used for description of contact problem.

Beam and column webs and flanges, bolts, screws and washers were modelled by using SOLID 8-node isoparametric three-dimensional solid elements. Three degrees of freedom are considered per node. Preloading of bolts was not evaluated.

The contact and separation problem between the end plates of the beam and the column is estimated in the numerical tests. The modelling of tree-dimensional contact problem is achieved through the use of node-to-surface GAP elements. Describing node-to-surface GAP elements, one surface of the body is marked by nodes of finite elements that cannot "adhere" or "cross" the indicated surface of another body. The initial gap distance between contacting bodies does not need to be specified by the user. All non-linear effects can be accounted for in the contact problems solution.

The welds strength between I sections of column and beam with end plates are assumed to be not less than parent metal and had no effect on the connection strength and stiffness. This allowed to simplify the modelling and accept directly agglutinate the beam and the column to the end plates.

The material of all types of finite elements is accepted as elastic-perfectly-plastic according to the codes on design of steel structures EC 3 [4]. The plasticity model is based on the von Mises yielding criteria.

To reduce the computational effort, only half of each connection was modelled, taking advantage of symmetry in the vertical plane along the column and beam axis.

The displacements in symmetry plane in the direction perpendicular to the symmetry plane and displacements of the bottom cross-section of the column in all directions were restrained to ensure real behaviour and symmetry of the connection.

\section{Numerical tests of not right angle bolted end plates beam-to-column connections}

The testing of finite element mesh density for accuracy of results was performed for connection $\mathrm{C} 10$. Practically acceptable results were achieved for finite element mesh with 6119 nodes, 2710 elements (Fig 3). This density of mesh was used for all other investigated connections.

Stress-strain states of connections when bending moment varies from zero to ultimate value were obtained by numerical tests. In connections A10, A20, A30 and $\mathrm{B} 10, \mathrm{~B} 20, \mathrm{~B} 30$ yield stresses are reached only in the bolts because they are too weak to transfer such forces so that plastic zones could occur in other parts of connections. In $\mathrm{C} 10, \mathrm{C} 20, \mathrm{C} 30$ yield stresses are reached in

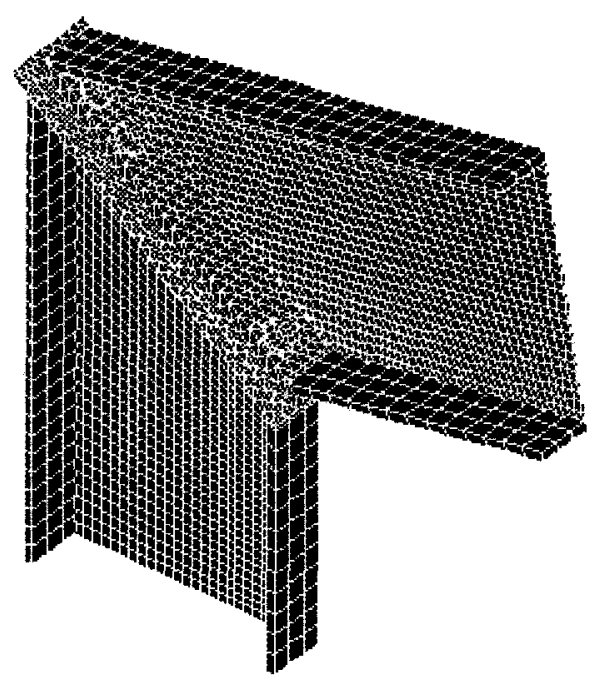

Fig 3. Three-dimensional finite element mesh of beam-tocolumn connection $\mathrm{C} 10$

bolts and elements that are in the tensional area of connections. Deformed model C30 and von Mises stresses distribution for bending moment, which equals $50 \%$, $75 \%$ and $100 \%$ of ultimate bending moment, are shown in Fig 4. Stresses are expressed in $\mathrm{kPa}$. Palette of the colours and stresses values are the same for all pictures in this Figure.

Moment-rotation M- $\Phi$ curves for all investigated connections are shown in Fig 5. The connection rotations were obtained as the difference of rotations of the middle lines of the beam and column elements \{18]. It can be stated by the shown curves that the inclination of beam has significant influence on the rigidity of this connection type. The smaller is the degree of the beam with the level contour, the more rigid is the connection, and vice versa.

Both the amount of bolts and their position in the tension area of the connection influence the rigidity of connections. M- $\Phi$ curves (Fig 5) show that the connection, having more bolts in tensional area, is more rigid than the same connection, having fewer bolts; and the connection with bolts moved further from the centre is more rigid than the same connection with bolts closer to the centre.

Moment-rotation M- $\Phi$ curves vary close to linearly and stresses in connections do not reach the yield limit, when the connections are affected by relatively small bending moments. The increase of rotation becomes more intensive when yield stresses occur and the plastic zones expand. For model C30 it is clearly seen in Figs 4 and 5. In connections, where not only bolts yield, the M$\Phi$ curves bend more flowingly than in models, where only bolts yield.

According to EC 3 beam-to-column connections, where the columns are not more rigid than beams for more than ten times, are treated as rigid if 
a)

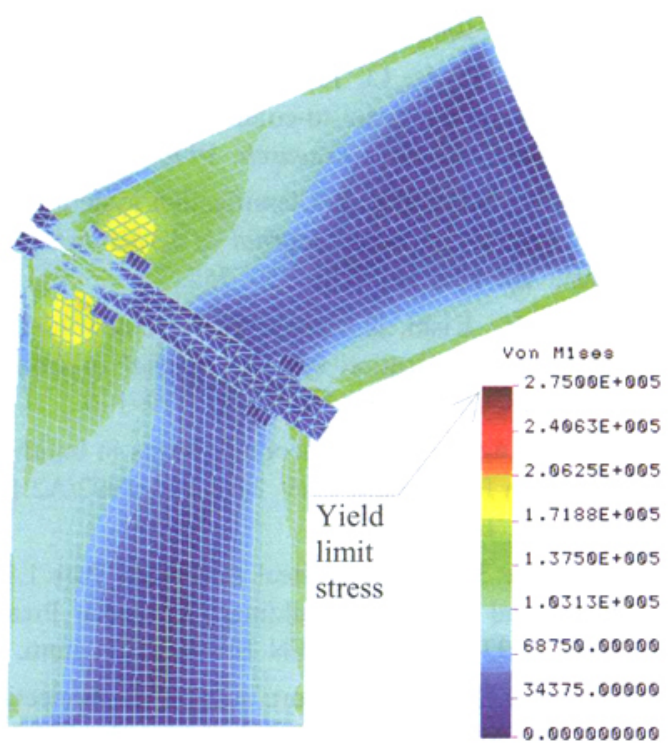

b)

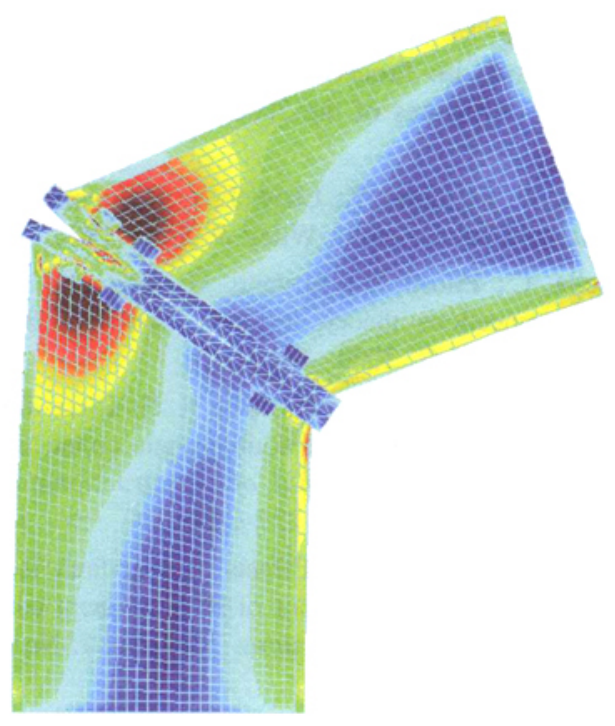

c)

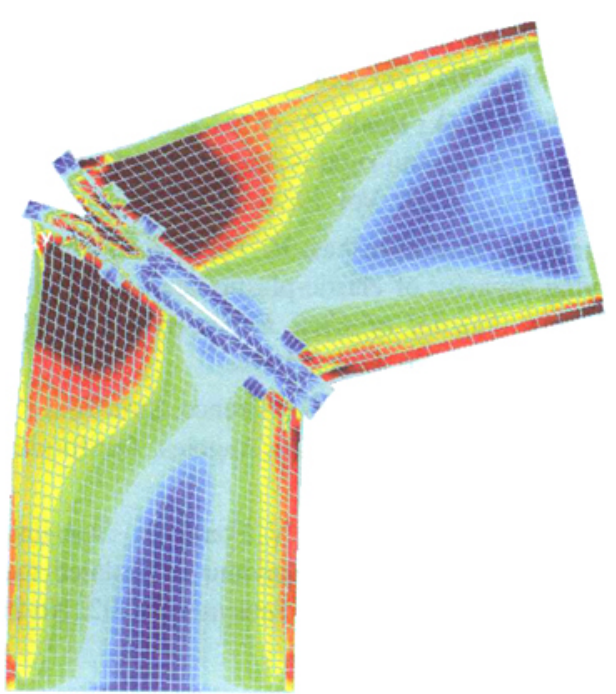

Fig 4. Deformed shape and von Mises stress distribution of connection $\mathrm{C} 30$ : bending moment value equals $50 \%$ (a), $75 \%$ (b), $100 \%$ (c) of ultimate bending moment a)

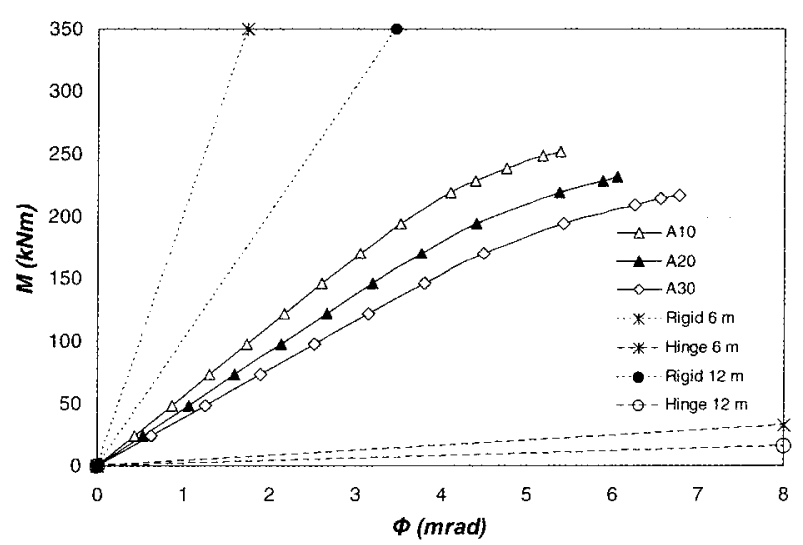

b)

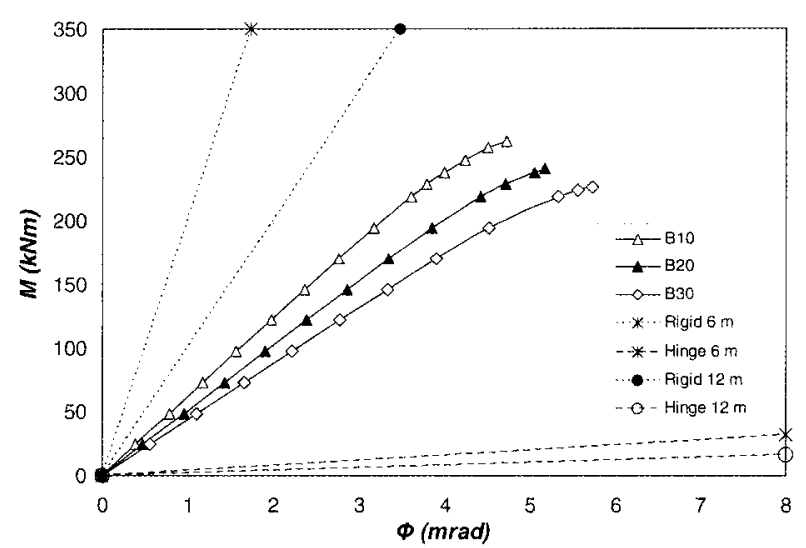

c)

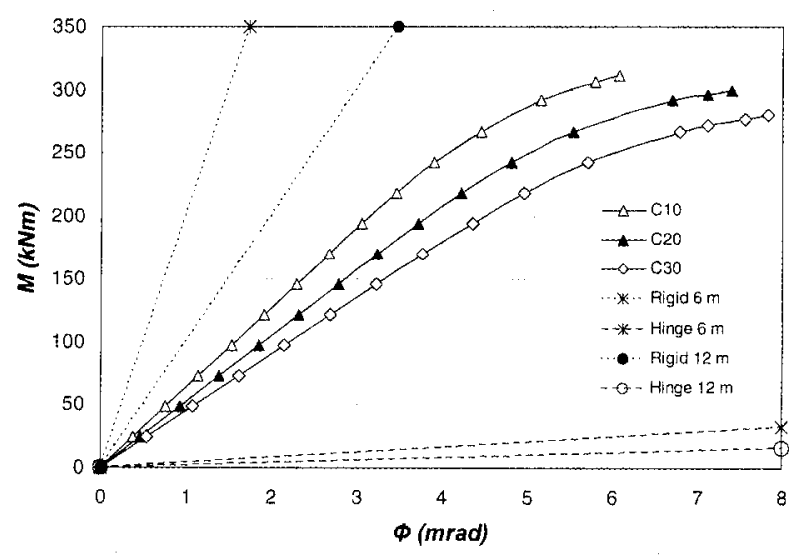

Fig 5. Moment-rotation M- $\Phi$ curves of beam-to-column connections and theoretical rigidity of connections according to EC 3: a) connections A10, A20, A30; b) connections B10, B20, B30; c) connections C10, C20, C30 
$S_{j, \text { ini }} \geq 25 E I_{b} / L_{b}$; connections are treated as hinged if $S_{j, \text { ini }} \leq 0,5 E I_{b} / L_{b}$, where $S_{j, i n i}$ - initial rotational stiffness; $E$ - steel elasticity modulus; $I_{b}$ - beam section second moment; $L_{b}$ - beam length. Connections that do not fall into the group of rigid and hinged connections are classified as semi-rigid [3,4]. Fig 5 shows theoretical limits of rigid and semi-rigid and semi-rigid and hinged connections according to code EC 3 [3], when the beam is 6 or $12 \mathrm{~m}$ long. The marking "Rigid $6 \mathrm{~m}$ " means the limit between rigid joints and semi-rigid joints according to $\mathrm{EC} 3$ when the beam length is $6 \mathrm{~m}$. The marking "Hinge $6 \mathrm{~m}$ " means the limit between semi-rigid joints according to EC 3 when the beam length is $6 \mathrm{~m}$. The marking ,Hinge $6 \mathrm{~m}^{\prime}$ means the limit between semirigid joints and hinged joints according to $\mathrm{EC} 3$, when the beam length is $6 \mathrm{~m}$. Analogous is the marking of limits when the beam length is $12 \mathrm{~m}$. Fig 5 shows that investigated connections according EC 3 falls in the group of semi-rigid joints.

\section{Conclusions}

The obtained moment-rotation $M-\Phi$ curves of numerical tests of beam-to-column connections indicate that the magnitude of angle between beam axis and the level contour has significant influence on the connection rigidity. The smaller is the angle of the beam and the level contour, the more rigid is the connection. This should be estimated in M- $\Phi$ curves obtained by analytical procedures.

The accepted model of beam-to-column connection numerical analysis by finite element method, including material and geometrical non-linearities and the contact and separation between connection components, permits to model real behaviour of beam-to-column connections. The presented numerical procedure of making $M-\Phi$ curves of joints on numerical tests results by using finite elements method can be applied as an effective method for evaluating the accuracy of $M-\Phi$ curves obtained by other methods.

The results of numerical tests indicate that all the analysed not right angle beam-to-column connections fall under the heading of semi-rigid joints according to EC 3 .

\section{References}

1. Hubert, G.; Tschemmernegg, F. Modelling of beam-to-column joints. Journal of Constructional Steel Research, 1998, Vol 45, No 2, p. 199-216.

2. van Keulen, D. C; Nethercot, D. A.; Snijder, H. H.; Bakker, M. C. M. Frames analysis incorporating semi-rigid joint action: Applicability of the half initial secant stiffness approach. Journal of Constructional Steel Research, 2003,
Vol 59, p. 1083-1100.

3. Nethercot, D. A.; Li, T. Q; Ahmed, B. Unified classification system for beam-to-column connections. Journal of Constructional Steel Research, 1998, Vol 45, p. 39-65.

4. Goto, Y.; Miyashita, S. Classification system for rigid and semirigid connections. Journal of Structural Engineering, 1998, Vol 124, No 7, p. 750-757.

5. Hasan, R.; Kishi, N.; Chen, W.-F. A new nonlinear connections classification system. Journal of Constructional Steel Research, 1998, Vol 47, p. 119-140.

6. Revised Annex $\mathrm{J}$ of Eurocode 3. Joints in building frames, European Prestandard ENV 1993-1-1:1992/A2:1998, CEN Brussels, Belgium.

7. Eurocode 3. Design of steel structures. Part 1.1: General Rules and Rules for Buildings, European Prestandard ENV 1993-1-1:1992, CEN Brussels, Belgium.

8. Jaspart, J. P. General report: session on connections. Journal of Constructional Steel Research, 2000, Vol 55, p. 69-89.

9. Kamerling, M. W. The design of steel frames with semirigid joints. In: Proceedings of International Conference on steel Structures of the 2000 's, Istanbul, 2000 , p. 101106.

10. Chen, W. F.; Goto, Y.; Liew, J. Y. R. Stability design of semi-rigid frames. John Wiley \& Sons. 1996. 468 p.

11. Faella, C.; Piluso, V.; Rizzano, G. Structural steel semirigid connections: theory, design and software. Boca Raton: CRC Press LLC, 2000. 494 p.

12. Yang, J.-G.; Murray, T. M.; Plaut, R. H. Three-dimensional finite element analysis of double angle connections under tension and shear. Journal of Constructional Steel Research, 2000, Vol 54, p. 227-244.

13. Yu, Q.-S.; Uang, C.-M. Effects of near-fault loading and lateral bracing on behaviour of RBS moment connections. Steel and Composite Structures, 2001, Vol 1, No 1, p. 145 158.

14. Kim, T.; Whittaker, A. S.; Gilani, A. S. J.; Bertero, V. V.; Takhirov, S. M. Cover-Plate and Flange-Plate Steel Moment-Resisting Connections. Journal of Structural Engineering, 2002, Vol 128, No 4, p. 474-482.

15. Markazi, F. D.; Beale, R. G.; Godley, M. H. R. Numerical modelling of semi-rigid boltless connectors. Computers and Structures, 2001, Vol 79, p. 2391-2402.

16. Jaras, A.; Kačianauskas, R. The investigation of load carrying capacity of elastic-plastic strain hardening I-sections beams. Journal of Civil Engineering and Management, 2002, Vol 8, No 1, p. 34-41.

17. COSMOS/M. Command reference. Structural Research and Analysis Corporation. Los Angeles, California. Copyright 2000. 883 p.

18. O. S. Bursi, F. Ferrario, V. Fontanari. Non-linear analysis of low-cycle fracture behaviour of isolated tee stub connections. Computers and Structures, 2002, No 80, p. 23332360. 